HABITAT, 28 (1), 2017, 28-36

DOI: 10.21776/ub.habitat.2017.028.1.5

\title{
Analisis Kepuasan Petani Bunga Krisan Potong terhadap Insektisida X di Desa Sidomulyo, Kecamatan Batu, Kota Batu
}

\section{Satisfaction Analysis of Crop-Chrysanthemum Farmers for using Insecticides $X$ in Sidomulyo Village, Batu Sub-District, Batu City}

\author{
Febriana Dian Indranisa Ramadhani ${ }^{1 *}$, Ratya Anindita ${ }^{2}$ \\ Jurusan Sosial Ekonomi, Fakultas Pertanian, Universitas Brawijaya Jl. Veteran, Malang (65145)
}

Recieved: 17 Mei 2017; Revised: 21 Juni 2017; Accepted:13 Juli 2017

\begin{abstract}
ABSTRAK
Tujuan penelitian ini untuk menganalisis tingkat kepuasan dan sekaligus menganalisis tingkat loyalitas petani bunga krisan potong terhadap penggunaan insektisida X. Metode yang digunakan adalah metode Importance Performance Analysis (IPA) dan Customer Satisfaction Index (CSI).Untuk mengukur tingkat kepuasan digunakan delapan variabel yaitu kinerja, keistimewaan tambahan, keandalan, kesesuaian dengan spesifikasi, daya tahan, serviceability, estetika, dan kualitas yang dipersepsikan. Kemudian untuk mengukur tingkat loyalitas, diukur dengan lima tingkatan loyalitas yaitu switcher, habitual buyer, satisfied buyer, liking the brand, committed buyer. Responden yang digunakan berjumlah 55 orang petani bunga krisan potong. Metode IPA menghasilkan rata-rata tingkat kesesuaian sebesar $104.53 \%$ dan menunjukan bahwa produk sudah dapat memenuhi harapan konsumen. Metode CSI menghasilkan tingkat kepuasan sebesar $71.6 \%$ dan termasuk dalam kriteria puas. Hasil analisis loyalitas menunjukan petani bunga krisan potong berada pada tingkat loyalitas liking the brand.
\end{abstract}

Kata kunci: kepuasan konsumen; loyalitas merek; insektisida

\begin{abstract}
The objective of this research is to analyze the level of satisfaction and loyalty of crop chrysanthemum's farmers toward insecticide X. The methods of the research are Importance Performance Analysis (IPA) and Customer Satisfaction Index (CSI). To measure the level of satisfaction used eight variables, involve performance, additional features, reliability, conformity with specifications, durability, serviceability, aesthetics, and perceived quality. Then to measure the level of loyalty, measured with five levels of loyalty, such as switcher, habitual buyer, satisfied buyer, liking the brand, committed buyer. Respondents are 55 crop chrysanthemum's farmers. IPA method gives the result of average suitability level of $104.53 \%$ and show that the product has been able to satisfy consumer expectations. CSI method gives the result of satisfaction level of $71.6 \%$ and includes in satisfied category. Therefore, the result of loyalty analysis showed crop chrysanthemum'sfarmers on the level of loyalty liking the brand.
\end{abstract}

Keywords: customer satisfaction; brand loyalty; insecticides

How to cite:

Dian Febriana, Indranisa, R., \& Anindita, R. (2017). Analisis Kepuasan Petani Bunga Krisan Potong terhadap Insektisida X di Desa Sidomulyo, Kecamatan Batu, Kota Batu. HABITAT, 28(1), 28-36. https://doi.org/10.21776/ub.habitat.2017.028.1.5

\section{Pendahuluan}

Kepuasan pelanggan merupakan kunci dalam menciptakan loyalitas pelanggan (Fornell, 1992). Setiap perusahaan memiliki tujuan yang sama, yaitu mendapatkan keuntungan yang maksimal dan terus berkembang usahanya. Dalam pandangan yang sama, tingkat maksimisasi keuntungan bergantung pada tingkat kepuasan

Available online at HABITAT website: http://www.habitat.ub.ac.id

ISSN: 0853-5167 (p); 2338-2007 (e) 
pelanggan, yang memiliki hubungan langsung dengan loyalitas pelanggan (Odunlami dan Matthew, 2015).

Kepuasan dan loyalitas konsumen adalah isu yang sangat penting dan menarik bagi mereka yang berkecimpung dalam bidang pemasaran produk ataupun jasa (Susila, Sumarwan, \& Kirbrandoko, 2014). Loyalitas merek sangat terkait dengan kepuasan konsumen. Semakin puas seorang konsumen terhadap suatu merek maka konsumen akan semakin loyal terhadap merek tersebut (Sumarwan, 2011; Mustikarini, Retnaningsih, \& Simanjutak, 2014).

Krisan (Dendranthema grandiflora) merupakan salah satu tanaman hias yang memiliki nilai ekonomi tinggi dan mempunyai peluang besar untuk meningkatkan taraf hidup petani (Wasito dan Komar 2004). Dalam penggunaannya, krisan dapat dibedakan atas krisan bunga potong dan krisan pot. Prospek agribisnis tanaman hias di dalam negeri sangat cerah dibandingkan dengan kondisi 10 tahun silam (Nurmalinda dan Hayati, 2014).

Bila dilihat pada posisi produksi, jumlah tangkai tanaman krisan dengan tanaman hias nonkrisan tahun 2002-2012 menunjukkan bahwa komoditas krisan menempati posisi tertinggi. Produksi krisan tahun 2013 mencapai 397.228.983 tangkai, sedangkan sedap malam hanya 100.387.599 tangkai, mawar 66.152.984 tangkai, dan anggrek 20.714.137 tangkai (Badan Pusat Statistik, 2013). Namun demikian meski terlihat bahwa produksi bunga krisan meningkat setiap tahun, petani bunga krisan pun tetap mengalami permasalahan dalam usahataninya.

Permasalahan yang sering dihadapi oleh petani krisan potong adalah hama. Hama thrips menjadi salah satu hama yang paling sering menyerang bunga krisan potong. Oleh karena serangan hama thrips yang dapat merugikan, maka petani memutuskan untuk menggunakan insektisida. Insektisida $\mathrm{X}$ adalah jenis insektisida kimiawi. Insektisida ini memiliki kandungan bahan aktif abamektin sebesar 36g/L, dimana abamektin dipercaya bahan paling ampuh untuk memberantas hama thrips tanaman (Purwanto, Hadiwidjojo, \& Ratnawati, 2013).

${ }^{*}$ Penulis korespondensi.

E-mail: dianfebriana8@gmail.com
Petani cenderung memilih insektisida disesuaikan dengan permasalahan yang dihadapi dan manfaat yang diberikan oleh insektisida tersebut (Sumarwan, 2011). Semakin tinggi nilai yang diterima petani, akansemakin tinggi pula tingkat kepuasan, dan sebagai akibatnya petani memutuskan untuk membeli insektisida dengan merek yang sama dengan pembelian sebelumnya (Rijanto, 2014; Purwanto, Hadiwidjojo, \& Ratnawati, 2013).

Petani bunga krisan potong di Desa Sidomulyo, Kecamatan Batu, Kota Batu telah menggunakan insektisida $X$ selama tiga tahun terakhir untuk membasmi hama thrips pada usahataninya. Petani sebagai konsumen sekaligus produsen bunga krisan potong tentu memperhatikan fungsi input permintaan dalam memilih produk apa saja yang digunakan. Mengingat harga $X$ yang cukup mahal dan petani diindikasikan merasa puas dan loyal akibat pembelian berulangkali selama tiga tahun, membuat penelitian ini menjadi penting dan menarik terkait kepuasan dan loyalitas pada insektisida X.

Di bidang pertanian, penelitian terhadap kepuasan dan loyalitas petani terhadap input pertanian sudah pernah dilakukan oleh beberapa peneliti baik terkait pestisida, benih maupun pupuk. Penelitian tersebut dilakukan olehMustikarini, Retnaningsih, \& Simanjutak (2014); Wicaksana, Muhaimin, \& Koestiono (2013).

Dengan mengembangkan penelitian yang sudah ada dan melihat fenomena di lapangan, dirumuskan beberapa tujuan dari penelitian ini antara lain (1) Menganalisis tingkat kepuasan petani bunga krisan potong terhadap insektisida $\mathrm{X}$ dan (2) Menganalisis tingkat loyalitas petani bunga krisan potong terhadap insektisidaX.

\section{Metode Penelitian}

Penelitian ini dilakukan di Desa Sidomulyo, Kecamatan Batu, Kota Batu. Pemilihan tempat didasarkan karena Desa Sidomulyo merupakan salah satu desa di Kota Batu yang dikenal sebagai sentra bunga hias dengan permintaan bunga krisan potong yang terus meningkat. Penelitian ini dilaksanakan pada bulan Maret-April 2017.

Jenis data yang digunakan adalah data primer berupa deep interview dan data sekunder dari BPS Kota Batu dan BPS Nasional berupa data

Available online at HABITAT website: http://www.habitat.ub.ac.id

ISSN: 0853-5167 (p); 2338-2007 (e) 
ekspor dan produksi bunga krisan potong. Metode penentuan sampel yang digunakan purposive sampling, yaitu penentuan sampel yang berdasarkan pada tujuan peneliti. Sampel yang digunakan disini adalah petani bunga krisan potong yang telah menggunakan insektisida $\mathrm{X}$ selama tiga tahun dan masih berlanjut sampai sekarang dengan jumlah sebanyak 55 petani.

\subsection{Analisis Kepuasan}

Menganalisis kepuasan petani bunga krisan potong di Desa Sidomulyo akan digunakan analisis Importance Performance Analysis (IPA) dan Customer Satisfaction Index (CSI). Seperti penelitian sebelumnya yang dilakukan oleh Mustikarini, Retnaningsih, \& Simanjutak (2014); Pohandry, Sidarto, \& Winarni (2013); dan Nugraha, Harsono, \& Adianto (2014).

Sebelum melakukan analisis menggunakan IPA dan CSI. Terlebih dahulu dilakukan pengujian terhadap instrumen yaitu berupa uji validitas dan realibilitas. Dimana uji validitas harus menunjukan nilai $\mathrm{r}$ hitung $>\mathrm{r}$ tabel. Uji realibilitas harus memiliki nilai Cronbach Alpha >0.7 (Ghozali, 2005).

\section{a. Importance Performance Analysis (IPA)}

Menurut Tjiptono (1997) kepuasan produk dapat diukur melalui delapan dimensi; yaitu kinerja, keistimewaan tambahan, keandalan, kesesuaian spesifikasi, daya tahan, serviceability, estetika, kualitas yang dipersepsikan. Penelitian oleh Ambarsari (2006); Irawan dan Japarianto (2013) mengembangkan teori tersebut untuk mengukur kepuasan terhadap sebuah produk. Pada penelitian ini, delapan dimensi tersebut diperluas menjadi 15 variabel pengukuran seperti pada Tabel 2 dan Tabel 4.

Analisis IPA menghitung skor total kinerja pelayanan dan kepentingan konsumen. Dan juga dilakukan perhitungan nilai rata-rata skor kinerja dan rata-rata skor kepentingan (Yola dan Budianto, 2013). Tahapan dalam analisis IPA adalah sebagai berikut:

1) Menghitung tingkat kesesuaian (Tki) antara tingkat kinerja dan kepentingan. Rumus untuk menghitung Tki sebagai berikut:

$T K i=\frac{X i}{Y i} \times 100 \%$.

Keterangan:

Tki adalah tingkat kesesuaian petani bunga krisan potong terhadap $X$, nilai ini didapat dengan membagi skor penilaian kinerja $X$ (Xi) dengan skor penilaian kepentingan $\mathrm{X}$ (Yi).

2) Menghitung rata-rata tingkat kepentingan dan tingkat kinerja dengan menggunakan rumus sebagai berikut:

$\bar{X}=\frac{\sum X i}{n}, \bar{Y}=\frac{\sum Y i}{n}$

Keterangan:

Rata-rata masing-masing variabel pada tingkat kinerja (Xi) dan kepentingan (Yi) didapat dengan cara membagi skor tersebut dengan jumlah petani bunga krisan potong yang dijadikan sampel (n).

3) Nilai rata-rata tingkat kepentingan secara keseluruhan item memotong sumbu vertikal tegak lurus dan nilai rata-rata tingkat kepuasan secara keseluruhan item memotong sumbu horizontal tegak lurus.

4) Nilai rata-rata tingkat kepentingan dan kepuasan pelanggan untuk setiap item diplotkan kedalam diagram pada Gambar 1. sebagai berikut:

$¥$ (Kepentingan)

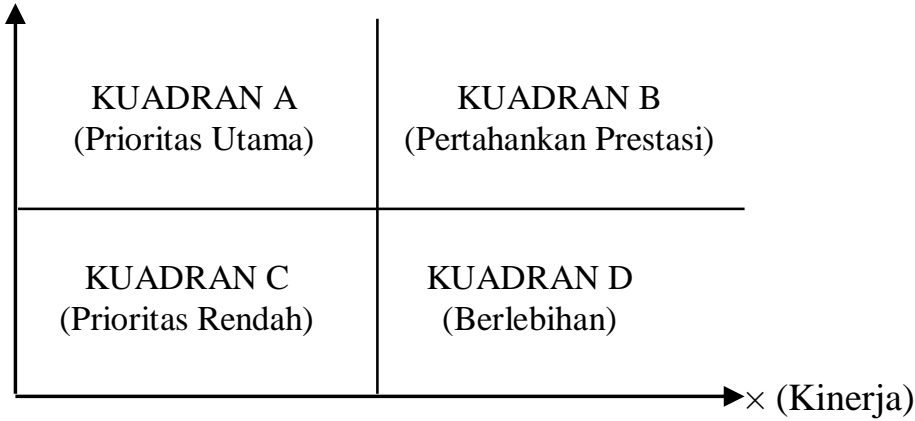

Gambar 1. Diagram Kartesius Sumber: Supranto (2001)

\section{b. Customer Satisfaction Index (CSI)}

Analisis CSI digunakan untuk mengukur tingkat kepuasan konsumen terhadap produk atau jasa dengan menghitung atribut-atribut pengukuran yang telah ditentukan. CSI dapat dihitung dengan tahapan berikut:

1) Menentukan Mean Importance Score (MIS). Nilai ini berasal dari rata-rata tingkat kepentingan tiap anggota. Rumus mencari MIS adalah sebagai berikut:

$M I S=\frac{\left(\sum_{i=1}^{n} Y i\right)}{n}$

Available online at HABITAT website: http://www.habitat.ub.ac.id

ISSN: 0853-5167 (p); 2338-2007 (e) 
Keterangan:

Nilai MIS didapat dengan cara membagi skor tingkat kepentingan masing-masing variabel (Yi) dengan jumlah sampel petani bunga krisan potong (n).

2) Menghitung Weighting Factors (WF), yaitu fungsi dari median tingkat kepentingan masing-masing atribut dalam bentuk persentase $(\%)$ dari total skor median tingkat kepentingan untuk seluruh atribut yang diuji. Rumus menghitung WF sebagai berikut:

$W F=\frac{M I S i}{\sum_{i=1}^{p} M I S} x 100 \%$

Keterangan:

Nilai WF didapat dengan cara membagi nilai MIS yang telah didapat dari masing-masing variabel (MISi) dengan total nilai MIS dari keseluruhan variabel $\left(\sum_{i=1}^{p} M I S\right)$ dan dikalikan dengan $100 \%$.

3) Menghitung Mean Satisfaction Score (MSS). Nilai ini berasal dari rata-rata tingkat kepuasan. Rumus menghitung MSS sebagai berikut:

$M S S=\frac{\left(\sum_{i=1}^{n} X i\right)}{n}$

Keterangan:

Nilai MSS didapat dengan cara menjumlahkan skor tingkat kinerja dan kepentingan dari masing-masing variabel $\left(\sum_{i=1}^{p} M I S\right)$ kemudian nilai tersebut dibagi dengan jumlah sampel (n).

4) Menghitung Weighted Score (WS), yaitu fungsi dari skor mean tingkat kepuasan (MSS) masing-masing atribut dikalikan dengan Weighting Factors (WF) masingmasing atribut.

5) Menghitung Weight Total (WT), yaitu total dari nilai Weighted Score (WS) secara keseluruhan.

6) Menghitung indeks kepuasan konsumen, yaitu perhitungan dari Weight Total (WT) dibagi skala maksimum, kemudian dikali $100 \%$ dan diinterpretasikan sesuai kriteria pada Tabel 2.

$C S I=\frac{W T}{5 Y} \times 100 \%$.

Keterangan:

$5 \mathrm{y}=$ skala maksimum
Tabel 1. Kriteria CSI

\begin{tabular}{cc}
\hline Nilai CSI & Kriteria CSI \\
\hline $0.00-0.34$ & Tidak Puas \\
$0.35-0.50$ & Kurang Puas \\
$0.51-0.65$ & Cukup Puas \\
$0.66-0.80$ & Puas \\
$0.81-1.00$ & Sangat Puas \\
\hline
\end{tabular}

Sumber: Sukardi dan Cholidis (2006)

\subsection{Analisis Loyalitas}

Menganalisis tingkat loyalitas digunakan analisis deskriptif dengan berdasar pada tingkatan menurut Aaker (1997) antara lain switcher, habitual buyer, satisfied buyer, liking the brand, committed buyer. Penelitian seperti ini pernah dilakukan oleh Mustikarini, Retnaningsih, \& Simanjutak (2014); Djamaludin, Sumarwan, \& Mahardikawati (2009).

Menganalisis tingkat loyalitas petani, pengukuran dilakukan dengan menggunakan skala likert, rata-rata, dan standar deviasi. Rumus yang akan digunakan untuk menghitung nilai rata-rata adalah sebagai berikut:

$\bar{X}=\frac{\sum X i . f i}{n}$

Keterangan:

Nilai rata-rata didapat dari penjumlahan skor frekuensi pengukuran dari keseluruhan indikator tingkat loyalitas (fi) yang sudah dikalikan dengan nilai skala (xi) kemudian dibagi dengan jumlah data (n).

Rumus mencari standard deviasi sebagai berikut:

$$
\begin{gathered}
\text { Standar Deviasi }= \\
\sqrt{\frac{\sum f i . x i^{2}-\frac{(\Sigma f i . x i)^{2}}{n}}{n-1}} \ldots \ldots \ldots \ldots \ldots \ldots
\end{gathered}
$$

Keterangan:

Nilai standar deviasi didapat dengan cara mencari nilai jumlah frekuensi skor yang sudah dikalikan dengan nilai skala dan dikuadratkan $\left(\Sigma f i . x i^{2}\right)$ yang dikurangi dengan nilai hasil dari pembagian antara jumlah frekuensi skor yang dikalikan dengan skala dan dikuadratkan $\left((\Sigma f i . x i)^{2}\right)$ dengan jumlah data (n). Kemudian nilai tersebut dibagi dengan jumlah sampel (n) dikurangi 1. Dan dicari akar kuadratnya. 


\section{Hasil dan Pembahasan}

\subsection{Kondisi Perkebunan Bunga Krisan Potong di Desa Sidomulyo}

Desa Sidomulyo adalah salah satu desa di Kota Batu yang dikenal sebagai sentra bunga. Di sepanjang jalan Desa Sidomulyo dapat dilihat berbagai tanaman hias yang dibudidayakan. Selain dibudidayakan, tanaman hias tersebut juga dipasarkan, bahkan konsumennya sudah hampir ke seluruh penjuru Indonesia. Kondisi permintaan akan bunga krisan potong di Desa Sidomulyo sampai saat ini (Maret 2017) masih dalam kondisi yang baik dan terus meningkat dari berbagai daerah.

Saat ini, pemasaran bunga krisan potong di Desa Sidomulyo dilakukan secara offline dan online. Untuk offline, petani bunga krisan potong memasarkan di sebuah toko di Jalan Utama Bukit Berbunga Desa Sidomulyo, sehingga mudah diakses oleh pengunjung dan wisatawan Kota Batu. Untuk pemasaran online, petani bunga krisan potong Desa Sidomulyo juga menjual hasil panen mereka di beberapa website khusus penjualan bunga secara online. Sejauh ini konsumen bunga krisan potong berasal dari daerah Surabaya, Nganjuk, Kediri, Probolinggo, Bali, Lombok, Sulawesi, dan masih banyak lagi. Para konsumen beranggapan bunga krisan potong dari Desa Sidomulyo lebih bagus dibanding bunga krisan dari daerah lain karena memiliki kelopak bunga yang lebih banyak, batang yang keras, dan juga bunga tersebut tidak mudah layu.

\subsection{Kepuasan Petani Bunga Krisan Potong di Desa Sidomulyo}

\subsubsection{Importance Performance Analysis (IPA)}

Tingkat kesesuaian antara kinerja dan kepentingan didapatkan dari hasil perbandingan kinerja dan kepentingan pada masing-masing variabel. Kesesuaian tersebut nantinya akan menentukan tingkat kepuasan petani pada masingmasing variabel.

Apabila suatu variabel menunjukan tingkat kesesuaian yang tinggi, maka kepuasan petani pun juga tinggi. Sebaliknya, jika nilai kesesuaian rendah, maka kepuasan petani akan variabel tersebut juga rendah. Tingkat kesesuaian yang tinggi akan tercapai apabila nilai tingkat kinerja melebihi tingkat kepentingan dari suatu variabel.
Tabel 2. menunjukan tingkat kesesuaian dari masing-masing variabel.

Tabel 2. Tingkat Kesesuaian Kinerja dan Kepentingan

\begin{tabular}{|c|c|c|c|}
\hline No & Dimensi & Variabel & $\begin{array}{c}\text { Tingkat } \\
\text { Kesesuian } \\
(\text { Tki) }(\%)\end{array}$ \\
\hline 1. & Kinerja & $\begin{array}{l}\text { Permasalahan } \\
\text { Hama Thrips } \\
\text { Kinerja } \\
\text { Produk } \\
\text { Hasil } \\
\text { Produksi }\end{array}$ & $\begin{array}{c}94.5 \\
100.53 \\
105.85\end{array}$ \\
\hline 2. & $\begin{array}{l}\text { Keistimewaan } \\
\text { Tambahan }\end{array}$ & $\begin{array}{l}\text { Kemudahaan } \\
\text { Penggunaan } \\
\text { Kemudahaan } \\
\text { Ditemukan }\end{array}$ & $\begin{array}{l}108.56 \\
104.39\end{array}$ \\
\hline 3. & Keandalan & Resiko & 110.26 \\
\hline 4. & $\begin{array}{l}\text { Kesesuaian } \\
\text { spesifikasi }\end{array}$ & Bahan Aktif & 106.5 \\
\hline 5. & Daya Tahan & Kehematan & 99.49 \\
\hline 6. & Serviceability & $\begin{array}{l}\text { Harga } \\
\text { Terjangkau } \\
\text { Kesesuaian } \\
\text { Harga }\end{array}$ & $\begin{array}{r}98.97 \\
102.62\end{array}$ \\
\hline 7. & Estetika & $\begin{array}{l}\text { Variasi } \\
\text { Kemasan } \\
\text { Kelengkapan } \\
\text { Petunjuk } \\
\text { Ketahanan } \\
\text { Kemasan }\end{array}$ & $\begin{array}{r}105.58 \\
105.02 \\
103.09\end{array}$ \\
\hline $\begin{array}{l}8 . \\
\text { Rata }\end{array}$ & $\begin{array}{l}\text { Kualitas yang } \\
\text { dipersepsikan } \\
\text { ata }\end{array}$ & $\begin{array}{l}\text { Merek } \\
\text { Produksi }\end{array}$ & $\begin{array}{l}111.98 \\
110.58 \\
104.53\end{array}$ \\
\hline
\end{tabular}

Hubungan kesesuaian antara tingkat kepentingan dan tingkat kinerja terhadap $\mathrm{X}$ sudah sangat baik dan sesuai. Menurut Sudaryanto dalam Purnomo (2015) jika presentase 80-100\% maka kesesuaian tersebut dapat dikatakan bahwa kinerja dari masing-masing variabel telah memenuhi harapan konsumen tetapi masih perlu dilakukan perbaikan lagi. Presentase $>100 \%$ dapat dikatakan kinerja variabel tersebut telah melebihi dengan harapan konsumen.

Selanjutnya metode IPA juga menghitung nilai rata-rata dari masing-masing kategori kinerja dan kepentingan. Rata-rata kategori kinerja sebesar 3.67 dan kategori kepentingan sebesar 3.51. Nilai 
tersebut akan menjadi garis $\mathrm{X}$ dan $\mathrm{Y}$ pada diagram kartesius.

Diagram kartesius merupakan suatu bangun yang dibagi atas empat bagian yang dibatasi oleh dua buah garis yang berpotongan tegak lurus pada titik-titik (x,y); dimana $\mathrm{x}$ merupakan rata-rata dari skor tingkat kinerja seuruh faktor dan y adalah ratarata dari skor tingkat kepentingan seluruh faktor yang mempengaruhi kepuasan pelanggan (Supranto, 2001).

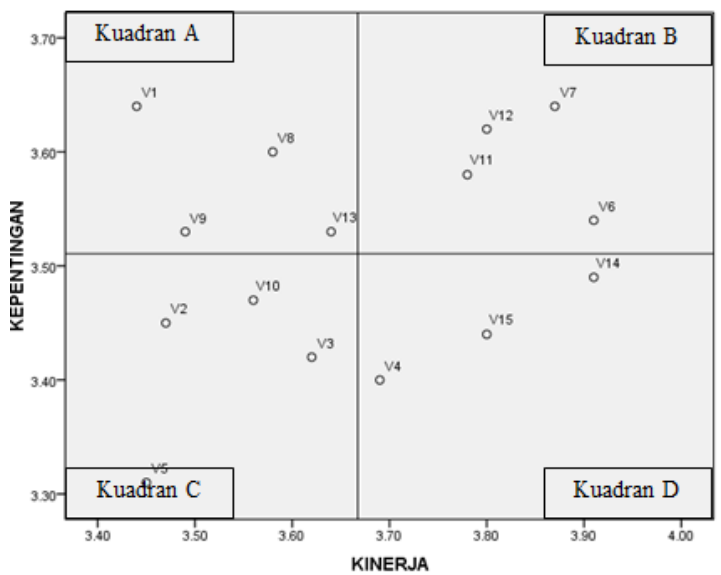

Gambar 2. Diagram Kartesius Petani Bunga Krisan Potong di Desa Sidomulyo

Berdasarkan diagram kartesius pada Gambar 2. dapat dilihat variabel-variabel sesuai dengan kuadrannya pada tabel berikut.

Tabel 3. Variabel berdasarkan Kuadran

\begin{tabular}{cl}
\hline Kuadran & \multicolumn{2}{c}{ Variabel } \\
\hline $\mathrm{A}$ & Permasalahan Hama Thrips (V1), \\
& Kehematan (V8), Harga \\
& Terjangkau (V9), Ketahanan \\
& Kemasan (V13) \\
& Resiko (V6) Bahan Aktif (V7), \\
& Variasi Kemasan (V11), \\
B & Kelengkapan Petunjuk (V12) \\
& Kinerja Produk (V2), Hasil \\
C & Produksi (V3), Kesesuaian Harga \\
& (V10), Kemudahan Ditemukan \\
& (V5) \\
& Kemudahan Penggunaan (V4), \\
& Merek (V14), Produksi (V15) \\
\hline
\end{tabular}

a. Kuadran A (Prioritas Utama)

Variabel-variabel yang berada pada kuadran ini adalah variabel-variabel yang belum maksimal sehingga perlu mendapat perhatian yang lebih dari perusahaan untuk dapat ditingkatkan.Seperti variabel permasalahan hama thrips dan variabel ketahanan kemasan harus segera ditingkatkan karena tidak memiliki kelebihan dibanding produk lain yang setipe. Selain itu, variabel kehematan harus ditingkatkan melihat harga dari $\mathrm{X}$ yang cukup mahal. Jika $X$ dapat memiliki harga yang terjangkau bukan tidak mungkin produk ini semakin diminati petani.

b. Kuadran B (Pertahankan Prestasi)

Pada kuadran ini berisi varabel-variabel yang memiliki tingkat kinerja dan tingkat kepentingan yang tinggi, sehingga sudah mampu mempengaruhi tingkat kepuasan petani. Akibat variabel resiko yang minim dari produk ini, variabel ini tidak perlu ditingkatkan. Bahan aktif yang terkandung pun sudah cukup membuat petani merasa puas akan dampak yang dirasakan. Oleh karena variasi kemasan yang bermacam-macam dan kelengkapan petunjuk dari masing-masing kemasan sudah lengkap, variabel-variabel ini tidak perlu ditingkatkan.

c. Kuadran C (Prioritas Rendah)

Variabel yang berada pada kuadran ini adalah variabel yang memiliki prioritas rendah untuk dilaksanakan pembenahan oleh perusahaan. Variabel kinerja produk dan hasil produksi memiliki tingkat kepentingan yang rendah namun kinerja dan praktiknya sudah cukup baik sehingga perusahaan perlu mempertimbangkan kembali jika ingin melakukan perubahan. Untuk variabel kesesuaian harga juga sudah cukup baik terbukti dari tingkat kesesuaian yang cukup tinggi. Dan juga $\mathrm{X}$ sudah cukup mudah ditemukan oleh petani bunga krisan potong.

d. Kuadran D (Berlebihan)

Pada kuadran ini menunjukkan variabelvariabel yang mempunyai tingkat kepentingan yang rendah, tetapi mempunyai tingkat kinerja yang tinggi. Oleh karena kelengkapan petunjuk dari X yang sudah sesuai dengan harapan petani, sehingga membuat merasakan mudah dalam menggunakan dan variabel kemudahan penggunaan dapat memuaskan petani. Variabel merek dan perusahaan yang memproduksi juga mampu memuaskan petani bunga krisan potong yang menganggap tingkat kepentingan dari dua variabel ini rendah. 


\subsubsection{Customer Satisfaction Index (CSI)}

Berdasarkan Tabel 4. dapat dilihat bahwa nilai dari CSI sebesar 71.6\%. Dimana nilai tersebut lebih tinggi dari $50 \%$ dan menandakan pelanggan merasa puas. Dan untuk lebih jelasnya menurut Sukardi dan Cholidis (2006) nilai CSI $71.6 \%$ atau 0.716 masuk ke dalam range $0.66-0.80$ dan merupakan kriteria puas.

Tabel 4. Perhitungan CSI

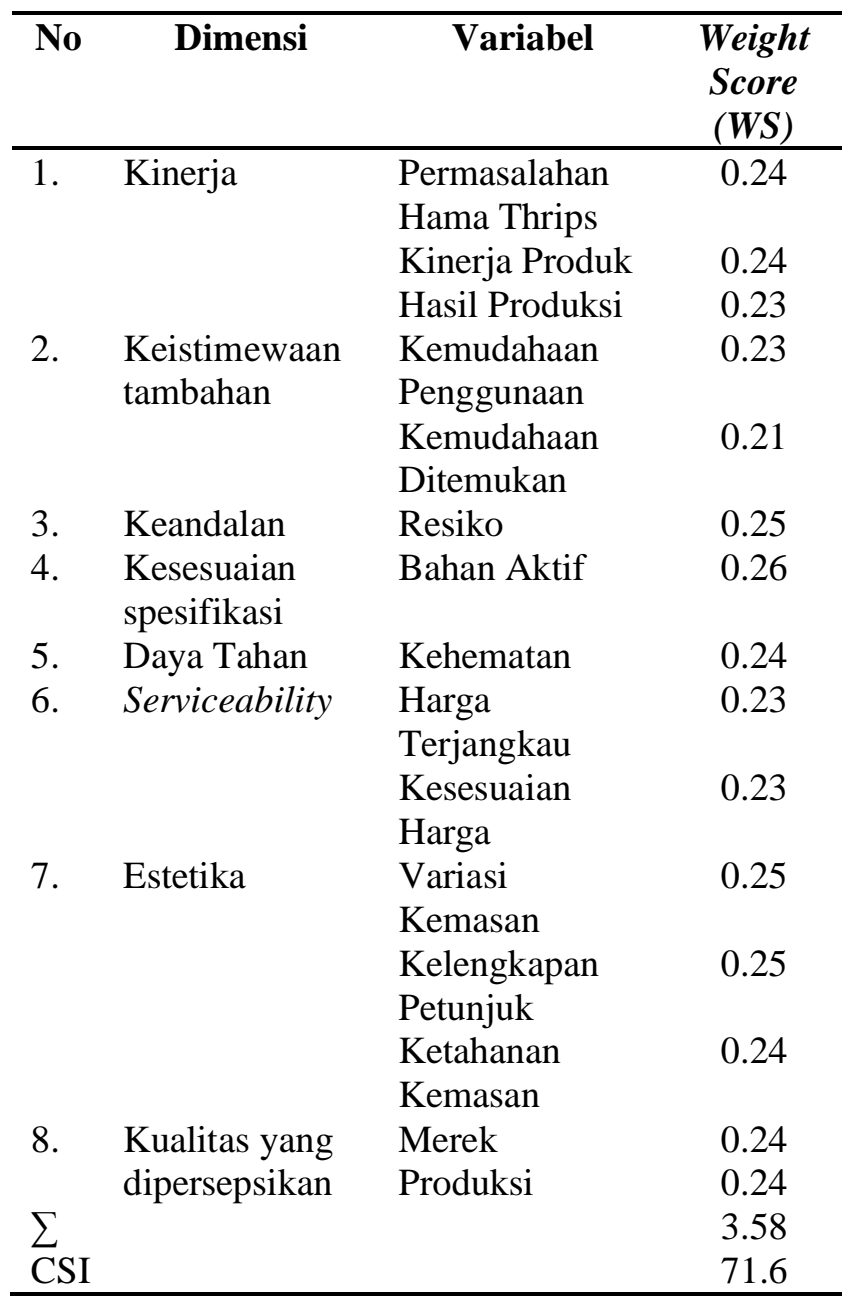

Jika analisis CSI dikaitkan dengan hasil analisis IPA, maka dapat disimpulkan bahwa nilai CSI yaitu sebesar $71.6 \%$ berasal dari variabelvariabel yang berada di kuadran B yaitu variabel yang memiliki tingkat kinerja dan kepentingan tinggi dan kuadran D yaitu variabel yang memiliki tingkat kinerja melebihi tingkat kepentingan yang rendah. Variabel-variabel pada kuadran tersebut sudah mampu menunjang tingkat kepuasan petani bunga krisan potong. Nilai CSI yang belum mencapai $100 \%$ berasal dari variabel-variabel yang belum bisa mendukung tingkat kepuasan petani bunga krisan potong, yaitu variabel yang berada pada kuadran A yaitu variabel yang memiliki tingkat kepentingan yang tinggi namun tingkat kinerja yang belum dapat memenuhinya dan $\mathrm{C}$ yaitu variabel yang memiliki tingkat kepentingan yang rendah namun tingkat kinerja sudah cukup memenuhinya. Oleh karena itu perlunya dilakukan perbaikan terhadap variabel berdasarkan hasil dari analisis IPA sehingga nantinya dapat meningkatkan nilai CSI.

\subsection{Loyalitas Petani Bunga Krisan Potong di Desa Sidomulyo}

Berdasarkan analisis deskriptif loyalitas petani bunga krisan potong di Desa Sidomulyo, dapat disimpulkan bahwa petani bunga krisan potong berada pada loyalitas tingkat kategori liking the brand. Dibanding dengan tingkat loyalitas lainnya seperti switcher, habitual buyer, satisfied buyer, liking the brand, dan committed buyer;petani yang merasa menyukai merek Xsebesar 54\%. Terdapat beberapa faktor mengapa mereka menyukai merek $\mathrm{X}$ yaitu karena merek tersebut sudah begitu lekat dengan usahatani bunga krisan potong selama beberapa tahun. Selain itu dikarenakan $\mathrm{X}$ merupakan salah satu insektisida yang memiliki harga yang cukup mahal, sehingga petani bunga krisan potong merasa memiliki prestige yang lebih tinggi jika menggunakan produk tersebut.

Dapat dilihat pula pada Gambar 3, tingkat loyalitas paling rendah berada pada habitual buyer yaitu sebesar $47 \%$. Petani bunga krisan potong di Desa Sidomulyo tidak merasa bahwa membeli $\mathrm{X}$ adalah sebuah kebiasaan, karena mereka selalu melakukan rotasi dalam penggunaan insektisida. Hal ini dilakukan agar hama yang menyerang tidak menjadi resisten saat pemberian insektisida. 


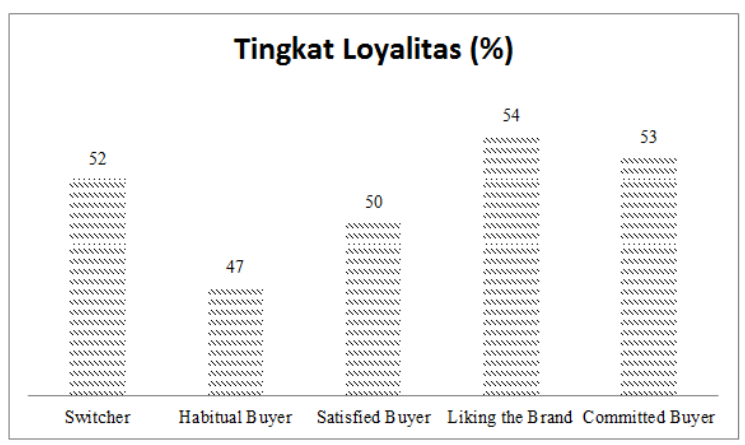

Gambar 3. Tingkat Loyalitas Petani Bunga Krisan Potong di Desa Sidomulyo

\section{Kesimpulan}

Kesimpulan dari penelitian ini antara lain:

a. Kepuasan petani bunga krisan potong di Desa Sidomulyo terhadap $\mathrm{X}$ berdasarkan analisis IPA didapatkan nilai rata-rata kesesuaian sebesar $104.53 \%$ dan dapat dikatakan sudah memenuhi harapan konsumen. Selain itu, didapatkan pula hasil variabel yang perlu mendapat perhatian dan pembenahan dari perusahaan adalah variabel Permasalahan Hama Thrips, Kehematan, Harga Terjangkau, Ketahanan Kemasan. Dan berdasarkan analisis CSI didapatkan nilai sebesar $71.6 \%$ atau 0.716 . Nilai tersebut masuk kedalam rentang nilai $0.66-0.80$. Rentang nilai tersebut mengindikasikan bahwa petani bunga krisan potong puas terhadap X.

b. Tingkat loyalitas petani bunga krisan potong terhadap $\mathrm{X}$, didapatkan hasil bahwa mayoritas petani masuk kedalam tingkatliking the brand. Hasil ini menunjukan petani bunga krisan potong sangat dekat dengan merek X. Emosional petani bunga krisan potong telah lekat dengan produk ini selama beberapa tahun.

Saran yang dapat direkomendasikan setelah penelitian ini dilakukan antara lain:

a. Sebaiknya perusahan produsen $\mathrm{X}$ diharapkan dapat melakukan pembenahan ulang terkait variabel yang masih belum menunjang tingkat kepuasan pengguna insektisida $X$.

b. Sebaiknya perusahaan melakukan pendekatan lagi terkait produk ASMEC 36 EC agar petani bisa lebih dari menyukai merek namun dapat menyarankan ke petani lain untuk menggunakan produk tersebut.

\section{Daftar Pustaka}

Aaker, David. 1997. Manajemen Ekuitas Merek. Jakarta: Spektrum.

Ambarsari, Yohana Candra. 2006. Pengaruh Kinerja Produk, Keistimewaan Tambahan, Keandalan, Kesesuaian dengan Spesifikasi, Serviceability, Daya Tarik Produk, Kualitas Yang Dipersepsikan sebagai Pembentuk Kepuasan Konsumen Terhadap Loyalitas Merek. Jurnal. Yogyakarta: Fakultas Ekonomi Universitas Sanata Dharma.

Badan Pusat Statistik. 2013. Perdagangan Internasional Tanaman Hias (online), <www. bps.go.id>.

Djamaludin, M. D., Sumarwan, U., \& Mahardikawati, G. N. A. 2009. Analisis kepuasan dan loyalitas konsumen jamu gendong di Kota Sukabumi.Jurnal Ilmu. Kel. \& Kons. Vol. 2, No.2:175-185.

Fornell, C. 1992. A National Customer Satisfaction Barometer: The Swedish Experience. Journal of Marketing, Vol. 56:6-21.

Ghozali. 2005. Aplikasi Analisis Multivariate Dengan Program SPSS. Semarang: Badan Penerbit Universitas Diponegoro.

Irawan, D dan Japarianto, E. 2013. Analisa Pengaruh Kualitas Produk Terhadap Loyalitas melalui Kepuasan Sebagai Variabel Intervening Pada Pelanggan Restoran Por Kee Surabaya. Surabaya: Jurnal Manajemen Pemasaran. Vol. 1, No. 2:1-8.

Mustikarini, F., Retnaningsih, \& Simanjutak, M. 2014. Kepuasan dan Loyalitas Petani Padi Terhadap Pestisida. Jur. Ilm. Kel. \& Kons. Vol. 7, No. 2:93-102.

Nugraha, R., Harsono, A., \& Adianto, H. 2014. Usulan Peningkatan Kualitas Pelayanan Jasa pada Bengkel " $X$ ” Berdasarkan Hasil Matrix Importance-Performance Analysis. Jurnal Teknik Industri Itenas. Vol. 1, No. 3: 221-231.

Nurmalinda dan Hayati. 2014. Preferensi Konsumen terhadap Krisan Bunga Potong dan Pot. J.Hort. Vol. 24, No. 4:363-372. 
Odunlami, B dan Matthew, O. 2015. Impact of Customer Satisfaction on Customer Loyalty: A Case Study of a Reputable Bank in Oyo, Oyo State, Nigeria. International Journal of Managerial Studies and Research (IJMSR). Vol. 3, No. 2:59-69.

Pohandry, A., Sidarto, \& Winarni. 2013. Analisis Tingkat Kepuasan Pelanggan Dengan Menggunakan Metode Customer Satisfaction Index Dan Importance Performance Analysis Serta Service Quality. Yogyakarta: Jurnal Rekavasi. Vol. 1, No. 1.

Purnomo, Wirdha. 2015. Analisa Kepuasan Pelanggan Terhadap Bengkel Dengan Metode Ipa (Importance Performance Analysis) Di Pt. Arina Parama Jaya Gresik. Surabaya: Jurnal JTM. Vol. 3, No. 3:54-63.

Purwanto, E., Hadiwidjojo, D., \& Ratnawati, K. 2013. Preferensi Merek Sebagai Pemediasi Pengaruh Kesadaran Merek dan Asosiasi Merek Terhadap Loyalitas Konsumen. Malang: Jurnal Aplikasi Manajemen. Vol. 11, No. 2:186-196.

Rijanto, Ong Andre W. 2014. Analisis Customer Satisfaction Index (Csi) Produk Dan Kepuasan Pelanggan Terhadap Kualitas Produk Umkm Rumput Laut Situbondo. Jurnal Media Mahardika. Vol. 12, No. 3:7384.

Sukardi dan Cholidis, C. 2006. Analisis Tingkat Kepuasan Pelanggan Terhadap Produk Cornet Produksi PT. CIP Denpasar. Bali: Jurnal Teknologi Industri Pertanian. Vol. 11, No.2:106-117.

Sumarwan, U. 2011. Perilaku Konsumen Teori Dan Penerapannya Dalam Pemasaran. Bogor: Ghalia Indonesia.

Supranto, J. 2001. Pengukuran Tingkat Kepuasan Pelanggan. Jakarta: Bineka Cipta.

Susila, Sumarwan, \& Kirbrandoko. 2014. Analisis Kepuasan Konsumen Terhadap Brand Switching Behavior Minuman Teh Dalam Kemasan. Jurnal Ilm. Kel. \& Kons. Vol. 7, No. 3:193-201.

Tjiptono, Fandy. 1997. Strategi Pemasaran. Edisi Kedua. Yogyakarta: ANDI.
Wasito, A., dan Komar, D. 2004. Pengaruh Jenis Pupuk terhadap Pertumbuhan dan Produksi Tanaman Krisan. J.Hort. Vol. 14, No. 3:1-5.

Wicaksono, B., Muhaimin, A., Koestiono, D. 2013. Analisis Sikap Dan Kepuasan Petani Dalam Menggunakan Benih Kentang Bersertifikat (Solanum Tuberosum L.). Jurnal Habitat. Vol. 24, No. 3:184-193.

Yola dan Budianto. 2013. Analisis Kepuasan Konsumen Terhadap Kualitas Pelayanan Dan Harga Produk Pada Supermarket Dengan Menggunakan Metode Importance Performance Analysis (IPA). Riau: Jurnal Optimasi Sistem Industri. Vol. 12, No.12:301-309.

Available online at HABITAT website: http://www.habitat.ub.ac.id

ISSN: 0853-5167 (p); 2338-2007 (e) 